\title{
PENGGUNAAN BENFORD'S LAW UNTUK MENENTUKAN PRIORITAS AUDIT PAJAK PERTAMBAHAN NILAI
}

\author{
Kristian Agung Prasetyo ${ }^{a}$, Mohammad Djufri ${ }^{b}$ \\ a Pusdiklat Pajak, Jakarta Barat Email: kristian.prasetyo@kemenkeu.go.id \\ b Pusdiklat Pajak, Jakarta Barat Email: mhd.djufri@gmail.com
}

\section{ABSTRACT}

Value Added Tax has contributed significantly in Indonesia's tax revenue and continually to progress in the term of its role in increasing the tax revenue. Unfortunately, the phenomenon of VAT fraud, intended to minimize VAT payment, would give consequences in violating the tax revenue. In order to minimize this phenomenon, DGT has been maximizing the use of technology in VAT administration. Since the 1st of July 2016, the use of e-Faktur has been enforced to all registered Taxable Entrepreneurs. The enforcement of the e-Faktur has been effectively reducing the number of counterfeit tax invoices. Nonetheless, the e-Faktur is still not be able to capture the accuracy of transactions in Tax Invoices. As a result, DGT relies heavily on the approach of conventional audit for auditing taxpayers' VAT compliance. This approach is considered to be less effective and become a problem since DGT does not have sufficient tax auditors. The number of tax invoices that needs to be audited could be piled up whilst the amount of tax credits to be audited are also high. This paper aims to discuss this problem by using a statistical technique namely Benford's law. It is recognized in the forensic audit literature that Benford's law can be a tool to help an early fraud examination of many transactions. By using particular statistical procedures, this paper will argue that Benford's Law can be used to analyze the accuracy of VAT value on tax invoices that is reported on the monthly VAT Return

Keywords: : VAT, audit, statistics, Benford's law

\section{ABSTRAK}

Pajak Pertambahan Nilai (PPN) memberikan kontribusi yang signifikan dalam penerimaan perpajakan dan peranannya terus meningkat dari tahun ke tahun. Adanya fraud PPN dapat menyebabkan hilangnya potensi penerimaan PPN karena dapat dipergunakan untuk meminimalkan pembayaran oleh Wajib Pajak. Sejak 1 Juli 2016, DJP telah mengimplementasikan e-Faktur bagi seluruh Pengusaha Kena Pajak terdaftar. Meskipun sistem ini diyakini efektif dalam mengurangi jumlah Faktur Pajak fiktif, e-Faktur belum mampu memeriksa keakuratan nilai transaksi yang dilaporkan dalam Faktur Pajak. Alhasil, DJP masih mengandalkan audit secara manual. Namun, banyaknya jumlah Faktur Pajak yang diterbitkan dan beban pekerjaan auditor untuk mengaudit kelebihan pembayaran pajak tampaknya membuat upaya audit manual 
belum menjadi jalan keluar yang tepat. Paper ini bertujuan untuk mengatasi masalah tersebut dengan teknik statistik yang dikenal sebagai Benford's Law. Konsep ini telah diakui dalam literatur audit forensik bahwa Benford's Law dapat dimanfaatkan sebagai alat untuk membantu deteksi dini kemungkinan transaksi fraud. Paper ini akan memaparkan bahwa Benford's Law dapat digunakan untuk menguji keakuratan nilai Faktur Pajak yang disampaikan oleh Pengusaha Kena Pajak di dalam SPT Masa PPN.

Kata Kunci: PPN, audit, statistika, Benford's law

\section{PENDAHULUAN}

\subsection{Peranan PPN terhadap Penerimaan Pajak}

Penerimaan perpajakan memiliki peran yang penting bagi pendapatan negara. Sebagai gambaran, penerimaan perpajakan mempunyai porsi sebesar Rp1.618,1 triliun atau 85,4\% dari seluruh pendapatan negara dalam APBN 2018 (Gambar 1).

Gambar 1

Struktur Pendapatan Negara

Sumber: Kementerian Keuangan

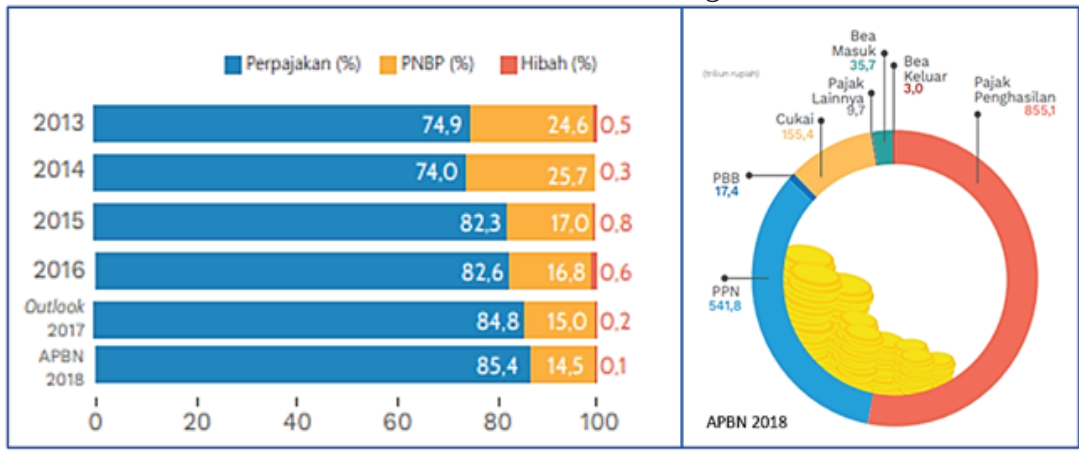

Salah satu jenis pajak yang cukup memberikan sumbangan besar bagi penerimaan perpajakan adalah Pajak Pertambahan Nilai (PPN). Pajak tersebut memiliki porsi sebesar 28,6\% dari total pendapatan negara pada tahun 2017. Selain itu, penerimaan PPN tersebut mengalami kenaikan sebesar 5\% dibandingkan tahun 2016 (Tabel 1). Hal ini sesuai dengan gambaran Charlet dan Buydens (2012) yang menyebutkan bahwa secara global PPN merupakan sumber penerimaan yang signifikan selain kontribusi jaminan sosial dan Pajak Penghasilan Orang Pribadi.

Tabel 1

Penerimaan Pajak (dalam triliun rupiah)

Sumber: Laporan Keuangan Pemerintah Pusat tahun 2017

\begin{tabular}{|l|r|r|r|r|}
\hline \multicolumn{1}{|c|}{ Jenis Pajak } & \multicolumn{1}{c|}{ TA 2017 } & \multicolumn{1}{c|}{ \% } & \multicolumn{1}{c|}{ TA 2016 } & \multicolumn{1}{c|}{ \% } \\
\hline Pajak Penghasilan & 646.793 & 56 & 666.212 & 60 \\
\hline $\begin{array}{l}\text { Pajak Pertambahan Nilai dan } \\
\text { Pajak Penjualan Barang Mewah }\end{array}$ & 480.725 & 42 & 412.213 & 37 \\
\hline Pajak Bumi dan Bangunan & 16.770 & 1 & 19.443 & 2 \\
\hline Pajak Lainnya & 6.739 & 1 & 8.105 & 1 \\
\hline Jumlah & 1.151 .027 & 100 & 1.105 .974 & 100 \\
\hline
\end{tabular}


Mengingat pentingnya peranan PPN ini, pemerintah selalu berupaya untuk mengevaluasi dan memperbarui berbagai kebijakan di bidang PPN dengan mempertimbangkan faktor -faktor yang mempengaruhi penerimaan PPN. Faktor-faktor tersebut, antara lain kondisi ekonomi negara, standar hidup masyarakat, kesadaran dalam pembayaran pajak, dan tax fraud (Bikas dan Andruskaite, 2013).

\subsection{Tax Fraud dan e-Faktur}

Fraud di dalam sistem administrasi PPN dapat mengakibatkan hilangnya potensi penerimaan PPN (Keen dan Smith, 2007). Menurut Walpole (2014), penyalahgunaan mekanisme pengkreditan Pajak Masukan dapat terjadi, misalnya dengan cara menggunakan Faktur Pajak fiktif untuk mendapatkan klaim Pajak Masukan secara ilegal. Menteri Keuangan Indonesia, Bambang Brodjonegoro, mengindikasikan bahwa terdapat sekitar 81\% dari 499 Wajib Pajak yang terdaftar di lima kanwil pajak besar, terbukti menggunakan Faktur Pajak fiktif. Selama tahun 2016 dan 2017 Direktorat Jenderal Pajak (DJP) telah menangani kasus Faktur Pajak fiktif sebanyak lebih dari 500 kasus dengan potensi kerugian negara mencapai angka lebih dari Rp1 triliun.Tindak lanjut atas banyaknya kasus Faktur Pajak fiktif tersebut, hingga 24 Januari 2018, DJP telah menonaktifkan Sertifikat Elektronik milik Wajib Pajak yang terindikasi menerbitkan Faktur Pajak tidak sah dengan jumlah sekitar 1.000 Wajib Pajak. $^{2}$
Sehubungan dengan hal tersebut, OECD menyatakan bahwa penggunaan teknologi dapat dimanfaatkan untuk meminimalkan penggunaan Faktur Pajak tidak sah, sekaligus untuk meningkatkan penerimaan pajak, menimbulkan efek jera, dan meningkatkan tingkat kepatuhan. Dalam hal ini, DJP telah menerapkan konsep tersebut berupa penerapan Faktur Pajak berbentuk elektronik (e-Faktur) yang pada dasarnya merupakan aplikasi komputer untuk membuat dan menerbitkan Faktur Pajak. ${ }^{3}$

Implementasi e-Faktur ini telah melalui rangkaian proses yang cukup panjang dan bukan program yang instan. Rangkaian proses tersebut, yaitu program registrasi ulang PKP untuk memastikan keberadaan Pengusaha Kena Pajak (PKP) yang potensial, meningkatkan treshold pengusaha yang wajib dikukuhkan sebagai PKP dari Rp 600 juta menjadi Rp 4,8 miliar, implementasi penomoran Faktur Pajak elektronik (e-Nofa) agar nomor Faktur Pajak tidak dibuat sendiri oleh PKP melainkan diberikan secara sistem oleh DJP, dan implementasi e-Faktur oleh seluruh PKP yang dilakukan secara bertahap mulai 1 Juli 2014 hingga 1 Juli 2016. Penerapan e-Faktur mengatur bahwa setiap Faktur Pajak yang diterbitkan oleh Pengusaha Kena Pajak harus mendapatkan persetujuan dari DJP dan hanya Faktur Pajak yang telah mendapatkan persetujuan dari DJP saja yang dapat dikreditkan. Dengan demikian, pemakaian Faktur Pajak fiktif relatif lebih mudah teridentifikasi. 
Namun, harus diingat bahwa Pasal 13 ayat (9) UU PPN menuntut persyaratan selain sah secara formal (pasal 13 ayat (5) UU PPN), Faktur Pajak juga harus memenuhi unsur material yaitu bahwa Faktur Pajak wajib berisi keterangan yang sebenarnya atau sesungguhnya. Alhasil, pada hakikatnya Faktur Pajak tidak memenuhi persyaratan material untuk dapat dikreditkan jika isi Faktur Pajak tersebut tidak mencerminkan nilai transaksi yang sebenarnya, meskipun persyaratan secara formal sudah terpenuhi berupa adanya pengesahan dari DJP melalui aplikasi e-Faktur.

Pengujian kebenaran material atas isi Faktur Pajak hanya dapat dilakukan melalui proses pemeriksaan. Namun, hal ini sering kali terkendala oleh banyaknya Faktur Pajak yang harus diperiksa. Sebagai gambaran, pada tahun 2013 DJP telah mengidentifikasi penerbitan sekitar 300 juta Faktur Pajak. Jumlah ini senantiasa meningkat dari tahun ke tahun. Pada saat yang sama, pemeriksa pajak mempunyai kewajiban untuk melakukan pemeriksaan terhadap permintaan restitusi atas kelebihan pembayaran pajak. Akibatnya, pemeriksaan untuk menguji unsur material Faktur Pajak sering kali kurang mendapatkan prioritas. Sebenarnya telah terdapat prosedur analisis risiko yang dilakukan oleh account representative untuk membantu pemeriksa pajak dalam memilah Wajib Pajak yang harus dilakukan pemeriksaan.
Namun, karena prosesnya yang relatif panjang, prosedur tersebut kurang efektif untuk membantu mengurangi beban pemeriksa pajak. Oleh karena itu, perlu diterapkan suatu metode yang efektif dan efisien untuk memilih Wajib Pajak yang harus dilakukan pemeriksaan. Dengan demikian, proses pemeriksaan dapat dilakukan dengan biaya yang lebih rendah dan dengan kualitas yang lebih baik karena jumlah Wajib Pajak yang harus diperiksa semakin sedikit (Schauer, 2012). Paper ini bertujuan untuk mengatasi masalah tersebut menggunakan teknik statistik yang disebut dengan Benford's law. Teknik ini dapat digunakan sebagai panduan untuk mendapatkan data awal bahan penelitian yang dapat dikembangkan lebih lanjut menjadi pemeriksaan. Sehingga, proses pemeriksaan Wajib Pajak dapat dilakukan dengan lebih efisien.

\section{KAJIAN LITERATUR \\ 2.1 Dasar Benford's Law}

Riwayat Benford's Law dimulai ketika seorang astronom Amerika bernama Simon Newcomb melihat bahwa kondisi kertas halaman-halaman awal buku logaritma lebih buruk dibandingkan halaman-halaman di akhir buku. Hal ini mengindikasikan bahwa orang cenderung memakai angka logaritma yang dimulai dengan digit kecil-seperti 1 atau 2-dibandingkan angka logaritma yang dimulai dengan digit besar, misalnya 9. Kemudian, Newcomb menghitung probabilitas munculnya suatu angka sebagai digit pertama atau kedua dalam suatu deret dan menerbitkannya dalam satu artikel ringkas pada tahun 1881. 
satu artikel ringkas pada tahun 1881. Namun, artikel Newcomb tersebut praktis terlupakan.

Setelah lebih dari 50 tahun, Frank Benford-peneliti di General Electric-menemukan bukti empiris yang sejalan dengan temuan Newcomb. Benford (1938) menemukan bahwa persentase rata-rata angka 1 muncul sebagai digit pertama pada angka yang timbul secara alamiah adalah sebesar 30\%. Angka yang dimaksud timbul secara alamiah tersebut, misalnya jumlah penduduk, panjang sungai, dan angka-angka yang muncul di Reader's Digest. Menurut Nigrini (2011) pola seperti ini dapat diharapkan muncul pada angka yang memenuhi kriteria sebagai berikut:

1. Angka tersebut mengukur fakta atau kejadian, seperti jumlah penduduk dan data keuangan.

2. Tidak ada batasan maksimum dan minimum, misalnya jumlah kredit pajak atas pajak yang sudah dibayar di luar negeri.

3. Angka tersebut bukan merupakan identitas, misalnya nomor KTP dan NPWP.

Secara umum di dalam Benford's law digariskan bahwa probabilitas angka tertentu muncul pada digit pertama suatu deret angka tidaklah sama rata sebesar $11,11 \%$. Selain itu, digit angka kecil-seperti 1 atau 2-mempunyai probabilitas untuk muncul sebagai digit pertama lebih besar dibandingkan angka yang nilainya lebih besar, seperti 8 atau 9 (Newcomb, 1881).
Sebagai contoh, angka 1 memiliki probabilitas sebesar kurang lebih 30\% untuk muncul sebagai angka digit pertama. Sementara itu, angka 9 mempunyai probabilitas kurang dari 5\% untuk muncul sebagai digit pertama. Kemudian, Benford (1938) menemukan bahwa probabilitas suatu angka muncul sebagai digit pertama adalah sebesar:

$$
P\left(D=d_{1}\right)=\log \left(1+\frac{1}{d_{1}}\right)
$$

dimana

$$
\begin{aligned}
& P\left(D=d_{1}\right) \text { : probabilitas munculnya angka d sebagai } \\
& \text { digit pertama. }
\end{aligned}
$$

Kemudian, probabilitas suatu angka muncul sebagai digit kedua dapat diestimasi menggunakan persamaan (Nigrini, 1996):

$$
P\left(D_{2}=d_{2}\right)=\sum_{d_{1}=1}^{9} \log \left(1+\left(\frac{1}{d_{1} d_{2}}\right)\right)
$$

dimana

$$
\begin{aligned}
P\left(D_{2}=d_{2}\right) & \text { : probabilitas munculnya angka } d_{2} \\
& \text { sebagai digit kedua pada suatu angka }
\end{aligned}
$$

Analisis selanjutnya dilakukan dengan membandingkan probabilitas munculnya dua digit pertama dengan probabilitas kemunculan kedua digit tersebut yang dihitung dengan persamaan (Nigrini, 2011):

$$
P\left(D_{1} D_{2}=d_{1} d_{2}\right)=\log \left(1+\left(\frac{1}{d_{1} d_{2}}\right)\right)
$$


Selain ketiga persamaan di atas, probabilitas suatu angka muncul pada posisi tertentu dapat pula dihitung dengan persamaan (Hill, 1995):

$$
P\left(D_{1}=d_{1}, \ldots, D_{k}=d_{k}\right)=\log \left[1+\left(\sum_{i=1}^{k} d_{i} \times 10^{k-i}\right)^{-1}\right]
$$

Sebagai conton, propabııtas muncuınya angka $14 /$ sepagai digit pertama sampai ketiga dalam suatu angka dapat diestimasi sebagai berikut (Nigrini, 1996):

$$
P\left(D_{1} D_{2} D_{3}=147\right)=\log \left(1+\frac{1}{147}\right) \cong 0.0029
$$

Sehingga, probabilitas kemunculan angka 0 sampai dengan 9 pada posisi digit pertama sampai dengan keempat dapat dilihat pada Tabel 2.

Tabel 2

Probabilitas kemunculan angka Sumber: Newcomb (1881), Nigrini (1996)

\begin{tabular}{ccccc}
\hline \multirow{2}{*}{ Digit } & \multicolumn{4}{c}{ Posisi } \\
\cline { 2 - 5 } & Ke-1 & Ke-2 & Ke-3 & Ke-4 \\
\hline 0 & & 0,11968 & 0,10178 & 0,10018 \\
\hline 1 & 0,30103 & 0,11389 & 0,10138 & 0,10014 \\
\hline 2 & 0,17609 & 0,10882 & 0,10097 & 0,10010 \\
\hline 3 & 0,12494 & 0,10433 & 0,10057 & 0,10006 \\
\hline 4 & 0,09691 & 0,10031 & 0,10018 & 0,10002 \\
\hline 5 & 0,07918 & 0,09668 & 0,09979 & 0,09998 \\
\hline 6 & 0,06695 & 0,09337 & 0,09940 & 0,09994 \\
\hline 7 & 0,05799 & 0,09035 & 0,09902 & 0,09990 \\
\hline 8 & 0,05115 & 0,08757 & 0,09864 & 0,09986 \\
\hline 9 & 0,04576 & 0,08500 & 0,09827 & 0,09982 \\
\hline
\end{tabular}

\subsection{Studi Terdahulu}

Hingga saat ini, Benford's law telah digunakan untuk menganalisis data-data numerik yang sifatnya alamiah (Kruger dan Yadavalli, 2017), seperti data-data keuangan, perpajakan, dan saham (Nigrini, 1999). Mujiono (2012) menggunakan Benford's law untuk melakukan analisis mengenai kewajaran transaksi BBM bersubsidi di Batam selama bulan Januari dan Februari 2010. Selain bidang keuangan, beberapa bidang yang telah menggunakan Benford's law antara lain pemodelan matematis, teknologi informasi, dan akuntansi (Stills, 2012). Benford's law sering digunakan dalam kegiatan auditing baik internal maupun eksternal (Nigrini dan Mittermaier, 1997). Auditor eksternal dapat menggunakan Benford's law untuk mengidentifikasi transaksi-transaksi tertentu yang harus diteliti lebih mendalam, sedangkan auditor internal dapat menggunakan Benford's law untuk mengidentifikasi transaksi yang diduga tak wajar. 
Auditor eksternal dapat menggunakan Benford's law untuk mengidentifikasi transaksi-transaksi tertentu yang harus diteliti lebih mendalam, sedangkan auditor internal dapat menggunakan Benford's law untuk mengidentifikasi transaksi yang diduga tak wajar.

Dalam bidang perpajakan, Busta dan Sundheim (1992) menunjukkan bahwa data yang tercantum dalam SPT cenderung mengikuti frekuensi pada Benford's law (Tabel 2), sehingga Benford's law dapat digunakan sebagai alat deteksi dini ketidakpatuhan (Morgan, et al., 1972). Dalam hal ini, Nigrini (1996) berhasil mendapatkan bukti empiris bahwa Wajib Pajak yang memiliki penghasilan rendah di Amerika Serikat memiliki kecenderungan lebih tinggi untuk memanipulasi isi SPT yang dilaporkan ke kantor pajak, dibandingkan Wajib Pajak berpenghasilan tinggi. Oleh karena itu, OECD (2010) merekomendasikan

penggunaan Benford's law sebagai sarana untuk melihat apakah suatu data keuangan yang dilaporkan oleh Wajib Pajak telah dimanipulasi atau tidak. Misalnya, nilai transaksi dalam Faktur Pajak, nilai penjualan tunai harian, atau isian palsu dalam laporan keuangan

\section{METODOLOGI}

\subsection{Deskripsi Data}

Tujuan paper ini adalah untuk menunjukan bahwa Benford's law dapat digunakan sebagai alat deteksi dini atas penyimpangan data di dalam Faktur Pajak.
Namun, terdapat kendala berupa tidak diperolehnya izin dari DJP untuk menggunakan data Faktur Pajak karena ketentuan kerahasiaan data Wajib Pajak. Oleh karena itu, paper ini tidak menggunakan data Faktur Pajak yang sebenarnya, namun menggunakan data dummy (rincian pembuatan data dummy dapat dilihat dalam lampiran). Meskipun tidak menggunakan data sebenarnya, prosedur penggunaan Benford's law tetap dapat diilustrasikan sepenuhnya karena data dummy yang dipakai, dirancang memiliki kemiripan karakteristik dengan data Faktur Pajak sebenarnya, sesuai dengan ringkasan data Faktur Pajak yang diperoleh peneliti.

Data ini disimpan menggunakan aplikasi Microsoft Excel disertai dengan nomor identitas dan klasifikasi lapangan usaha untuk setiap Pengusaha Kena Pajak (PKP). Pengolahan data selanjutnya dilakukan dengan program Microsoft Excel 2019 (Excel) dan Minitab versi 19 (Minitab). Secara keseluruhan, paper ini meyimulasikan 125.121 data Faktur Pajak senilai lebih dari Rp 500 triliun dari 22.467 Pengusaha Kena Pajak selama tahun 2011. Sehingga, simulasi dapat memenuhi rekomendasi minimal data yang diperlukan, yaitu 300 butir data (Nigrini, 2012).

Faktur Pajak yang paling banyak disampaikan adalah Faktur Pajak PKP di sektor penyediaan minuman keliling /tempat tidak tetap dengan jumlah 702 faktur. Di sisi lain, Faktur pajak paling sedikit disampaikan oleh PKP di bidang perdagangan besar barang dari kertas dan karton dengan jumlah 78 faktur. 


\subsection{Persiapan Data}

Proses utama di dalam analisis Benford's law adalah pemisahan digit-digit tertentu. Pemisahan digit ini dilakukan menggunakan Excel sebagai alat bantu. Paper ini hanya menggunakan uji Benford's law primer yang terdiri atas uji digit pertama, kedua, dan dua digit pertama (Nigrini, 2012). Jenis uji Benford's law yang lain-disebut dengan uji Benford's law lanjutansebenarnya mempunyai kemampuan yang lebih luas karena dapat dipergunakan untuk menguji angka yang sebenarnya tidak dapat dianalisis menggunakan uji Benford's law primer. Namun, jenis uji tingkat lanjut ini tidak dipergunakan di dalam paper ini karena memerlukan jumlah data yang relatif banyak dan perhitungan matematis yang cukup kompleks.

Digit pertama dan dua digit pertama pada nilai faktur pada daftar pengenaan pajak dalam setiap Faktur Pajak diperoleh menggunakan fungsi LEFT() pada Excel, sedangkan untuk digit kedua diperoleh menggunakan fungsi MID(). Kemudian, proses selanjutnya menghitung frekuensi relatif untuk setiap digit dan membandingkannya dengan frekuensi Benford's law pada Tabel 2.

Uji digit pertama pada dasarnya bersifat umum sehingga hanya dapat mendeteksi ketidaknormalan yang sifatnya ekstrem (Nigrini, 2012). Uji digit kedua pun pada hakikatnya mempunyai karakteristik yang hampir sama. Hal ini berbeda dengan uji dua digit pertama yang mempunyai akurasi yang lebih tinggi dibandingkan dengan kedua uji digit sebelumnya karena uji dua digit pertama dapat dipergunakan untuk mengidentifikasi anomali data sampai tingkat transaksi. Dengan demikian, uji ini relatif sesuai untuk kepentingan perpajakan yang dilaporkan di dalam SPT Masa PPN, khususnya terkait Faktur Pajak. Frekuensi Benford's law untuk analisis ini dapat dihitung menggunakan persamaan (3) atau persamaan (4). Proses analisis kesesuaian antara frekuensi riil dengan frekuensi digit Benford's law akan diuraikan pada bagian selanjutnya.

\subsection{Uji Kesesuaian}

Pada bagian sebelumnya telah disampaikan bahwa kesesuaian dengan frekuensi digit Benford's law pada hakikatnya mengindikasikan ketidaknormalan data. Namun, harus diingat bahwa kesesuaian dengan frekuensi Benford's law tidak selalu mengindikasikan bahwa suatu data terbebas dari manipulasi sebagaimana ditunjukkan oleh Özera dan Babacan (2013). Di sisi lain, ketidaksesuaian dengan frekuensi Benford's law sudah selayaknya membuat kita lebih berhati-hati dalam memaknai data sebagaimana telah ditunjukkan oleh Varian (1972). Hal tersebut disebabkan oleh adanya kemungkinan pihak yang memanipulasi data tidak menggunakan pola pikir algoritmik-sebagaimana ditunjukkan pada persamaan (1) sampai dengan persamaan (4)-seperti yang digariskan dalam Benford's law (Pomykacz, Olmsted, dan Tantinan, 2017). Hal ini bermanfaat untuk mengetahui kemungkinan bahwa data tersebut telah dimanipulasi (Özera dan Babacan, 2013).

Bagi data yang jumlahnya relatif sedikit, biasanya kesesuaian dengan 
frekuensi Benford's law dapat diestimasi secara visual menggunakan histogram. Namun, bagi data yang jumlahnya besar, hal ini relatif lebih problematis karena hasilnya cenderung kurang akurat. Oleh karena itu, Nigrini (2012) menyatakan bahwa analisis secara visual sebaiknya dilengkapi dengan beberapa uji statistik, seperti uji Z, chi square, Kolmogoroff-Smirnoff, atau mean absolute deviation (MAD). Selain itu, uji statistik pelengkap juga dapat menggunakan root mean square error (RMSE) dan uji proporsi (Kruger dan Yadavalli, 2017). Paper ini menggunakan uji Z untuk menguji kesesuaian dengan frekuensi Benford's law. Dalam hal ini, nilai $Z$ dihitung menggunakan persamaan (6) (Nigrini, 2012):

dimana:

$$
Z=\frac{|A P-E P|-\left(\frac{1}{2 N}\right)}{\sqrt{\frac{E P(1-E P)}{N}}}
$$

$\begin{array}{ll}\text { AP } & \text { : frekuensi digit tertentu } \\ \text { EP } & \text { : frekuensi Benford's law } \\ \text { K } & \text { : jumlah data. }\end{array}$

Pada dasarnya uji Z digunakan untuk menentukan apakah perbedaan antara frekuensi suatu digit tertentu dengan frekuensi Benford's law memiliki nilai signifikan secara statistika. Dalam hal ini, tingkat signifikasi yang dipergunakan adalah sebesar 0,05 sehingga nilai $Z$ yang menjadi patokan adalah sebesar 1,96 (Nigrini, 2012). Maknanya, jika nilai Z hitung yang dikalkulasi menggunakan persamaan (6) lebih dari 1,96, dapat disimpulkan bahwa frekuensi digit tersebut berbeda secara signifikan dengan frekuensi Benford's law.
Ketidaksesuaian dengan frekuensi Benford's law mengindikasikan adanya ketidaknormalan data yang sudah seharusnya diteliti lebih mendalam meskipun tidak selalu berarti terdapat fraud. Dengan demikian, Benford's law dapat digunakan dalam tahap awal pemilihan PKP yang perlu diperiksa. Sehingga, proses audit dapat dilakukan dengan lebih efisien.

\section{ANALISIS DATA}

Paper ini menggunakan uji digit pertama, kedua, dan dua digit pertama. Uji digit ini dilakukan atas nilai transaksi terutang PPN yang dilaporkan PKP dalam data dummy SPT Masa PPN setiap bulan. Frekuensi digit yang sebenarnya kemudian dibandingkan dengan frekuensi Benford's law (Tabel 2). Untuk setiap digit, MAD kemudian dihitung dan dibandingkan dengan nilai cut off.

\subsection{Analisis Digit Pertama}

Analisis digit pertama pada hakikatnya ditujukan untuk memperoleh gambaran umum atas data yang sedang dianalisis. Hal ini dilakukan karena analisis digit pertama hanya dapat mendeteksi ketidaksesuaian yang benar-benar nyata saja. Alhasil, meskipun terdapat ketidaknormalan pada data yang dianalisis, analisis digit pertama terkadang tetap menunjukkan tingkat kesesuaian yang baik dengan Benford's law (Nigrini, 2012). Hasil analisis digit pertama dapat dilihat dalam Tabel 3. 
Tabel 3

Uji digit pertama

Sumber: Hasil analisis

\begin{tabular}{|c|c|c|c|}
\hline \multirow{2}{*}{ Angka } & \multicolumn{2}{|c|}{ Frekuensi } & \multirow{2}{*}{$\begin{array}{c}\text { Sesuai } \\
\text { dengan } \\
\text { Benford? }\end{array}$} \\
\hline & Nyata & Benford & \\
\hline 1 & 0.290 & 0.301 & Tidak \\
\hline 2 & 0.171 & 0.176 & Tidak \\
\hline 3 & 0.122 & 0.125 & Tidak \\
\hline 4 & 0.104 & 0.097 & Tidak \\
\hline 5 & 0.078 & 0.079 & $\mathrm{Ya}$ \\
\hline 6 & 0.068 & 0.067 & Ya \\
\hline 7 & 0.059 & 0.058 & $\mathrm{Ya}$ \\
\hline 8 & 0.060 & 0.051 & Tidak \\
\hline \multirow[t]{2}{*}{9} & 0.048 & 0.046 & Tidak \\
\hline & & MAD: & 0.00439 \\
\hline
\end{tabular}

Tabel 3 menunjukkan bahwa secara keseluruhan data transaksi yang dilaporkan oleh PKP relatif sesuai dengan Benford's law ( $N=125.118$, MAD=0.00439). Secara visual terlihat bahwa data Faktur Pajak yang dianalisis telah sesuai dengan Benford's law (Gambar 2).

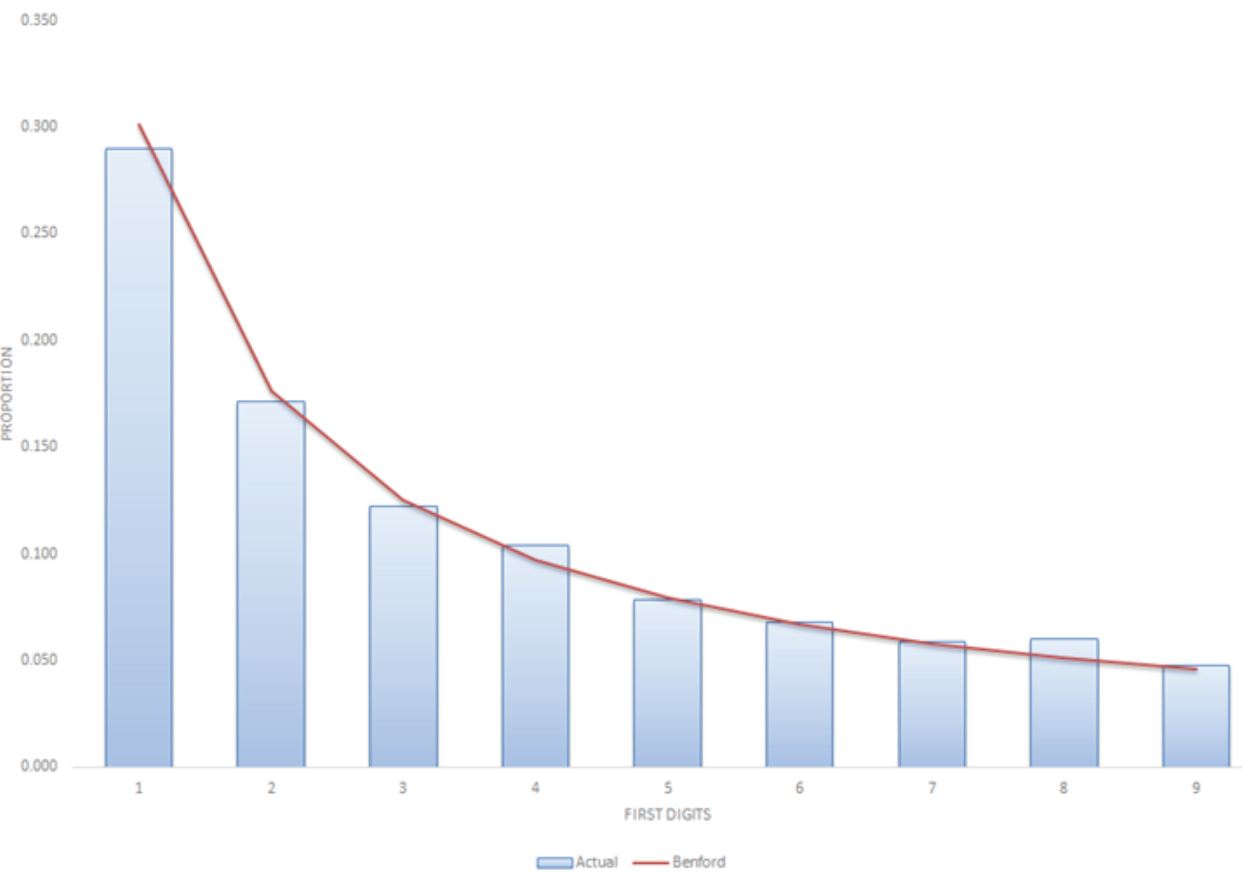


Namun, jika diperhatikan uji Z menunjukkan bahwa terdapat enam kelompok digit yang mempunyai perbedaan signifikan dengan frekuensi Benford's law. Kelompok ini terdiri atas data Faktur Pajak yang transaksinya dimulai dengan angka 1 sampai 4 dan angka 8 sampai 9. Secara keseluruhan, terdapat 99.471 data Faktur Pajak yang tidak sesuai dengan Benford's law. Hasil saringan uji digit pertama menunjukan bahwa terdapat kemungkinan PKP melaporkan data tidak wajar dengan jumlah sekitar $80 \%$ dari keseluruhan Faktur Pajak.

Tabel 3

Uji digit pertama

Sumber: Hasil analisis

\begin{tabular}{|c|c|c|c|}
\hline \multirow{2}{*}{ Angka } & \multicolumn{2}{|c|}{ Frekuensi } & \multirow{2}{*}{$\begin{array}{c}\text { Sesuai } \\
\text { dengan } \\
\text { Benford? }\end{array}$} \\
\hline & Nyata & Benford & \\
\hline 0 & 0.126 & 0.120 & Tidak \\
\hline 1 & 0.109 & 0.114 & Tidak \\
\hline 2 & 0.107 & 0.109 & Tidak \\
\hline 3 & 0.104 & 0.104 & Ya \\
\hline 4 & 0.098 & 0.100 & Tidak \\
\hline 5 & 0.099 & 0.097 & Tidak \\
\hline 6 & 0.091 & 0.093 & Tidak \\
\hline 7 & 0.093 & 0.090 & Tidak \\
\hline 8 & 0.088 & 0.088 & Ya \\
\hline \multirow[t]{2}{*}{9} & 0.085 & 0.085 & $\mathrm{Ya}$ \\
\hline & & MAD: & 0.00228 \\
\hline
\end{tabular}

Sebagaimana halnya dengan digit pertama, uji digit kedua (Gambar 3) menunjukkan bahwa data Faktur Pajak yang dianalisis secara keseluruhan relatif sesuai dengan Benford's law ( $=125.118, \mathrm{MAD}=0.00228)$.

Namun, hanya terdapat tiga kelompok angka dari sepuluh kelompok angka yang tidak mempunyai perbedaan signifikan dengan frekuensi Benford's law, yaitu 34.687 Faktur Pajak yang digit keduanya adalah 3, 8, dan 9. Sedangkan, sisanya mempunyai perbedaan yang signifikan. Secara keseluruhan, terdapat 90.426 Faktur Pajak yang terindikasi tidak sesuai dengan Benford's law. Salah satu hal menarik yang didapat dari uji digit kedua adalah adanya 15.767 Faktur Pajak yang mempunyai digit kedua 0 terindikasi tidak sesuai dengan Benford's law. Hasil yang lebih detail selanjutnya dapat diperoleh dari analisis dua digit pertama. 
Gambar 3

Uji digit kedua

Sumber: Data diolah

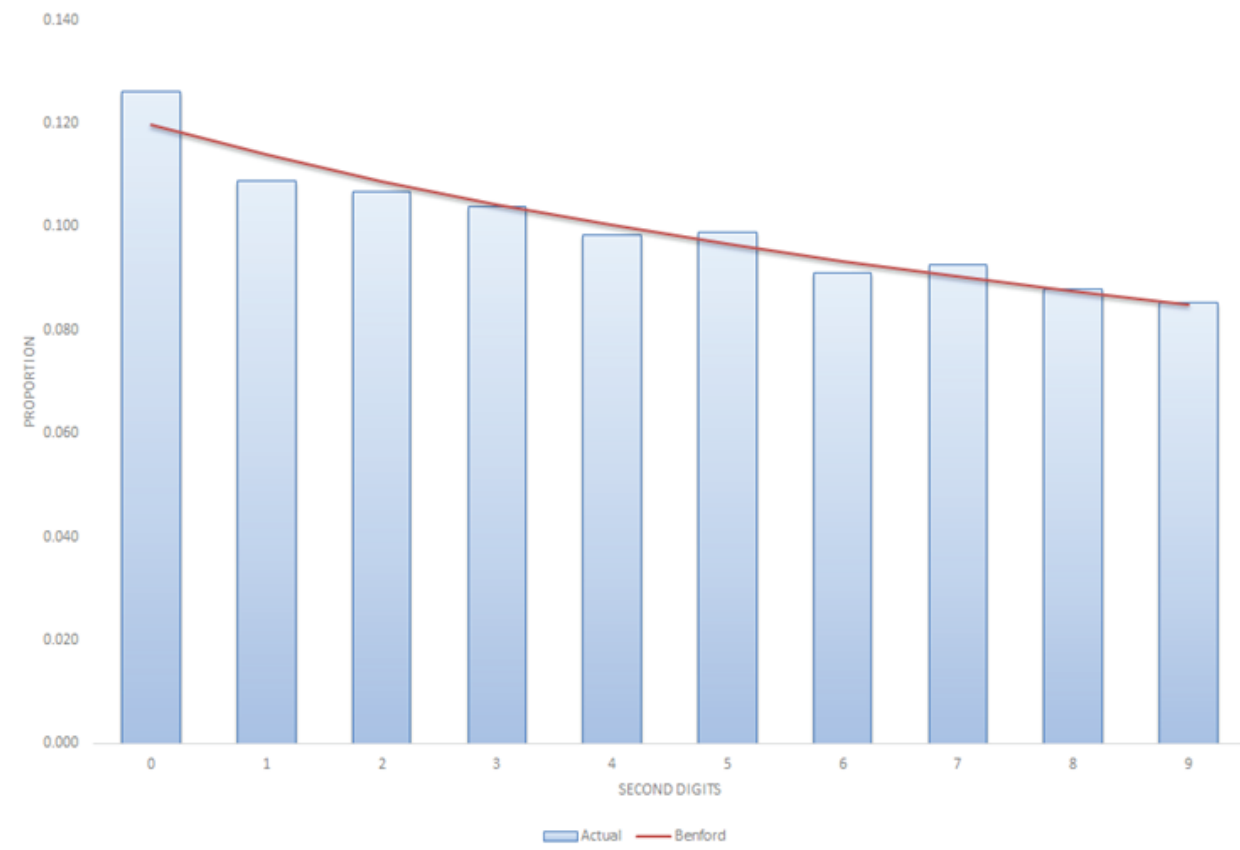

\subsection{Analisis Dua Digit Pertama}

Analisis dua digit pertama mempunyai tingkat akurasi yang lebih baik dibandingkan dengan dua analisis sebelumnya. Analisis ini menunjukkan bahwa secara keseluruhan, data Faktur Pajak yang dianalisis menunjukkan adanya kesesuaian dengan Benford's law ( $N=125.118, M A D=0.00070)$. Dari 90 kelompok data yang analisis, yaitu digit 10 sampai dengan digit 99, terdapat 41 kelompok yang mempunyai perbedaan signifikan dengan Benford's law. Kemudian, sisanya relatif sudah sesuai dengan frekuensi Benford's law dengan jumlah sebanyak 49 kelompok data. Data PKP yang tergabung dalam kelompok yang tidak sesuai dengan Benford's law ini sebaiknya dapat dijadikan sebagai bahan awal untuk diteliti lebih lanjut bagi pemeriksa pajak. Histogram uji dua digit pertama disajikan pada Gambar 4.

Terdapat beberapa hal menarik yang ditunjukan oleh Gambar 4. Pertama, uji dua digit pertama menunjukkan adanya data Faktur Pajak yang hanya mempunyai satu digit saja, yaitu 1 dan 3, sebanyak empat faktur untuk masing-masing digit. Tentu saja data tersebut menarik karena pada dasarnya relatif tidak mungkin ada pengusaha yang melakukan penyerahan senilai Rp 1,00 atau Rp 3,00 saja. Hal seperti ini sudah seharusnya menjadi perhatian pemeriksa pajak karena kecil kemungkinan terdapat penyerahan dengan nilai seperti itu.

Kedua, meskipun secara umum analisis atas dua digit pertama menunjukkan kesesuaian dengan Benford's law. 
Gambar 4

Uji dua digit pertama

Sumber: Hasil analisis

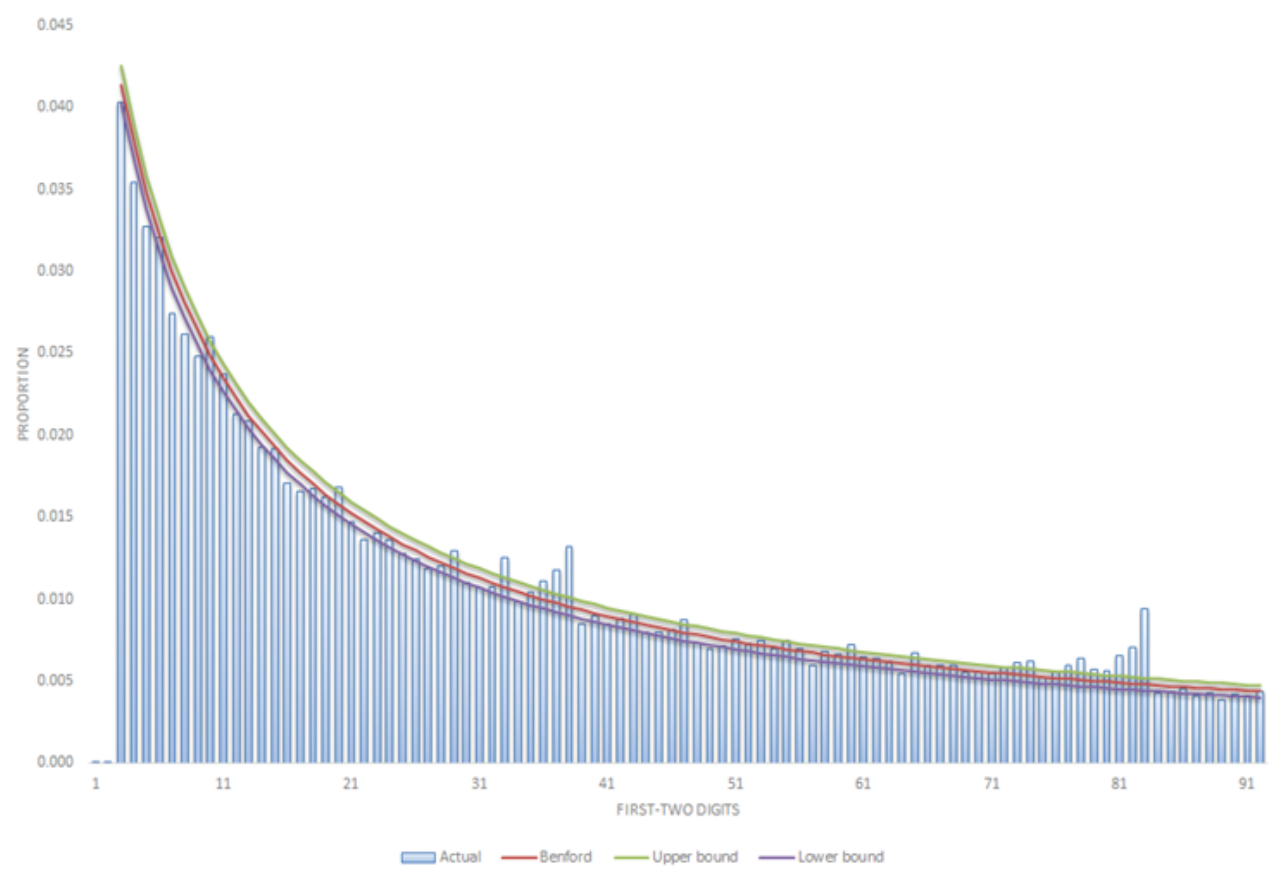

di beberapa titik masih terlihat ada ketidaksesuaian. Sebagai contoh, faktur yang mempunyai DPP yang diawali dengan angka 90 pada Gambar 4 terlihat jelas tidak sesuai dengan Benford's law. Berdasarkan hasil uji Z, diketahui bahwa kelompok faktur ini mempunyai perbedaan yang signifikan dengan frekuensi Benford's law $(Z=23.730, \alpha=0.05)$. Kemudian, data simulasi menunjukan bahwa terdapat 1.181 Faktur Pajak yang diawali dengan angka 90 diterbitkan oleh PKP di 261 KPP. Dengan demikian, rata-rata di setiap KPP hanya terdapat empat Faktur Pajak yang harus diteliti. Kemudian, Faktur Pajak yang diawali dengan angka 90 tersebut paling sedikit diterbitkan oleh PKP di 57 KPP, yaitu sejumlah 1 faktur. Sementara itu, Faktur Pajak yang diawali dengan angka 90 paling banyak diterbitkan oleh 23 PKP yang terdaftar di KPP dengan kode 922, yaitu sejumlah 23 faktur. Hasil pengolahan data juga dapat mengidentifikasi NPWP atas PKP yang menerbitkan Faktur Pajak tersebut. Analisis seperti ini dapat diulangi untuk titik-titik lain dengan kondisi serupa, seperti Faktur Pajak dengan DPP yang dimulai dengan angka 45 ( $Z=13.206, \alpha=0.05)$.

\section{SIMPULAN DAN SARAN}

Salah satu cara untuk meningkatkan tingkat kepatuhan Wajib Pajak, setidaknya secara ekonometri, adalah dengan meningkatkan kemampuan aparat pajak untuk mendeteksi fraud. Namun, dalam praktik, khususnya PPN, hal ini sering terkendala oleh sedikitnya jumlah pemeriksa pajak, 
sedangkan jumlah Faktur Pajak yang harus diperiksa sangat banyak. DJP berusaha mencari solusi atas kondisi tersebut dengan menerapkan aplikasi e-Faktur dan adanya prosedur analisis risiko. Namun, dalam kenyataannya e-Faktur tidak dapat digunakan untuk meneliti kebenaran data transaksi yang dilaporkan PKP dalam SPT Masa PPN. Demikian halnya dengan analisis risiko, masih relatif terkendala karena proses analisis yang masih harus dikerjakan secara manual.

Untuk mengatasi masalah tersebut, paper ini mengusulkan pemakaian Benford's law sebagai alat untuk menyaring Wajib Pajak yang akan diperiksa. Berdasarkan hasil kajian literatur diketahui bahwa Benford's law telah teruji secara empiris untuk digunakan sebagai deteksi dini atas kemungkinan terjadinya fraud. Dengan demikian, kontribusi paper ini adalah menunjukkan bagaimana Benford's law dapat digunakan dalam konteks PPN.

Namun, data yang digunakan dalam paper ini adalah data hasil simulasi dan bukan data sebenarnya, karena terdapat unsur kerahasiaan data Wajib Pajak. Dengan demikian, hasil yang disajikan harus dipahami hanya sebagai penjelasan atas prosedur analisis. Tentunya hasil analisis akan lebih sempurna jika dapat dilakukan terhadap data Wajib Pajak yang sebenarnya.

\section{DAFTAR PUSTAKA}

[1] Ainsworth, R. T. (2006). Carousel Fraud in the EU: A Digital VAT Solution. Tax Notes International, May 1, 2006, 443-448.

[2] Benford, F. (1938). The Law of Anomalous Numbers. Proceedings of the American Philosophical Society, 78(4), 551-572. www.jstor.org/stable/984802.

[3] Bikas, E. \& Andruskaite, E. (2013). Factors Affecting Value Added Tax Revenue. Annual International Interdisciplinary Conference, AllC 2013, 24-26 April 2013. Portugal.

[4] Busta, B. \& Sundheim, R. (1992). Tax return numbers tend to obey Benford's law. Center for Business Research Working Paper No. W93-106-94. Minnesota: St. Cloud State University.

[5] Charlet, A \& Buydens, S. (2012). The OECD International VAT/GST Guidelines: past and future developments. World Journal of VAT/GST Law, 1(2), 175-184. Diakses dari https://www.oecd.org/ctp/consumption/OE CDInternation a IVATGST GuidelinesWorld\%20Journal.pdf

[6] DJP. (2018). DJP suspend 1.049 WP Terindikasi Penerbit Faktur Ilegal. Diakses dari http://www.pajak.go.id/djp-suspend-1049-wp-terindikasi-penerbit-faktur-ilegal

[7] Hill, T. (1995). A Statistical Derivation of the Significant-Digit Law. Statistical Science, 10(4), 354-363. www.jstor.org/stable/2246134

[8] Keen, M. \& Smith, S. (2007). VAT Fraud and Evasion: What Do We Know, and What Can be Done. IMF Working Paper No 07/31. Diakses dari https://www.imforg/en/Publications/WP / I s s u e s/2016/12/31/ VAT-Fraud-and-Evasion-What-Do-We-Knowand-What-Can-be-Done-20215

[9] Kruger, P. \& Yadavalli, S. (2017). The power of one: Benford's Law. South African Journal of Industrial Engineering, 28(2), 1-13. doi:10.7166/28-2-1753.

[10] Morgan, J., Deaton, A., Cramer, E., Bibby, J., Wiorkowski, J., Moore, R., \& Varian, H. (1972). Letters to the Editor. The American Statistician, 26(3), 62-66. www.jstor.org/stable/2682871. 
[11] Mujiono. (2012). Pemanfaatan Spreadsheet Microsoft Excel untuk Pembelajaran Benford's Law pada Kasus Analisa Data Transaksi BBM Bersubsidi, Konferensi Nasional Pembelajaran Informatika 2012, 21 Januari 2012. Yogyakarta.

[12] Newcomb, S. (1881). Note on the Frequency of Use of the Different Digits in Natural Numbers. American Journal of Mathematics, 4(1), 39-40. doi:10.2307/2369148.

[13] Nigrini, M. J. (1996). A Taxpayer Compliance Application of Benford's Law. Journal of the American Taxation Association, 18(1), 72-91.

[14] Nigrini, M. J. (1999). I've Got Your Number: How a mathematical phenomenon can help CPAs uncover fraud and other irregularities. Journal of Accountancy, 187(5), 79-83.

[15] Nigrini, M. J. (2011). Forensic Analytics: Methods and Techniques for Forensic Accounting Investigations. New Jersey: John Wiley \& Sons, Inc.

[16] Nigrini, M. J. (2012). Benford's Law: Applications for Forensic Accounting, Auditing, and Fraud Detection. New Jersey: John Wiley \& Sons, Inc.

[17] Nigrini, Mark J., \& Mittermaier, L. J. (1997). The Use of Benford's Law as an Aid in Analytical Procedures. Auditing: A Journal of Practice \& Theory, 16(2), 52-67.

[18] OECD. (2017). Technology Tools to Tackle Tax Evasion and Tax Fraud. Paris: OECD Publishing. Diakses dari https://www.oecd.org/tax/crime/technolo$g \mathrm{y}-\mathrm{t} 0 \mathrm{ol} \mathrm{s}-\mathrm{t} 0$ - $\mathrm{t}$ a c k le-tax-evasion-and-tax-fraud.pdf

[19] OECD. (2010). Guidance Note: Guidance on Test Procedures for Tax Audit Assurance. Paris: OECD Publishing. Diakses dari https://www. oecd.org/tax/forum-on-tax-administration/publications-and-products/technologies/4504541 4.pdf

[20] Özera, G. \& Babacan, B. (2012). Benford's Law and Digital Analysis: Application on Turkish Banking Sector. Business \& Economics Research Journal, 4(1), 29-41.
[21] Peraturan Direktur Jenderal Pajak Nomor Per-19/PJ/2017 tentang Perlakuan terhadap Penerbitan dan/atau Penggunaan Faktur Pajak Tidak Sah oleh Wajib Pajak.

[22] Pomykacz, M., Olmsted, C., \& Tantinan, K. (2017). Benford's Law in Appraisal. The Appraisal Journal, Fall, 274-284.

[23] Radu, L. (2012). An Analysis on Combating Vat Fraud in The European Union Using New IT Technologies. Bulletin of the Transilvania University of Brasov. Series V: Economic Sciences. 2 (51).

[24] Schauer, R. (2012). Statistical Sampling in Tax Compliance Auditing in the USA. Dikutip dalam Robert F van Brederode (ed.). Science, Technology, and Taxation. Netherlands: The Kluwer Law International.

[25] Stills, S. (2012). Benford's Law. Dikutip dalam Leonard M. Wapner (ed.). Unexpected Expectations: The Curiosities of A Mathematical Crystal Ball. New York: CRC Press.

[26] Walpole, M. (2014). International - Tackling VAT Fraud. IBFD Journal Articles - VAT: International Vat Monitor, 25(5). 


\section{LAMPIRAN}

\section{Proses Pembuatan Data Dummy}

Salah satu kendala dalam penulisan paper ini adalah terbatasnya akses data Faktur Pajak. Untuk mengatasi kendala tersebut, peneliti diberikan ringkasan atas data Dasar Pengenaan Pajak (DPP) yang tersimpan di dalam sistem informasi DJP untuk tahun 2011. Data ringkasan ini terdiri atas Kelompok Lapangan Usaha (KLU), jumlah Wajib Pajak untuk setiap KLU, dan ringkasan DPP Faktur Pajak untuk setiap KLU. Ringkasan DPP tersebut terdiri atas mean DPP, DPP maksimum, minimum, nilai tengah, kuartil pertama, dan kuartil ketiga DPP. Secara keseluruhan terdapat 845 baris ringkasan data. Sebagian isi ringkasan data seperti terdapat dalam tabel berikut ini.

\begin{tabular}{rrrrrrr}
\hline KLU & Count & Minimum & Q1 & Q2 & Q3 & Maximum \\
\hline 13111 & 156 & 2272727 & 42849523 & 200972102 & 1209592054 & $2.81162 \mathrm{E}+11$ \\
13121 & 234 & 909091 & 34357205 & 132495673 & 596669046 & $2.41090 \mathrm{E}+11$ \\
13123 & 79 & 500000 & 75000000 & 231789525 & 633683454 & 51218017186 \\
13131 & 78 & 3807455 & 51051590 & 258603046 & 1111595273 & $3.03601 \mathrm{E}+11$ \\
13133 & 156 & 378925 & 39291474 & 150641795 & 640492046 & 40366431253 \\
13134 & 158 & 1265000 & 57597079 & 236231153 & 783156887 & 13137938365 \\
13912 & 79 & 1636364 & 46548428 & 198846910 & 836187492 & $5.31158 \mathrm{E}+11$ \\
13913 & 237 & 500000 & 80454186 & 234919818 & 898022728 & 71919109457 \\
13921 & 79 & 3600000 & 49850000 & 177533270 & 436735901 & 3134379076 \\
13922 & 79 & 2542182 & 47410927 & 121775000 & 427301550 & 34807959322 \\
13923 & 79 & 1137549 & 57729550 & 229176060 & 1240913103 & 67506406441 \\
13924 & 158 & 1048000 & 52072452 & 133153089 & 500186581 & 21999427909 \\
13991 & 158 & 1100000 & 50357134 & 196856955 & 933478435 & 21653506681 \\
13993 & 78 & 909909 & 60987501 & 199993114 & 920033636 & $1.02918 \mathrm{E}+11$ \\
13994 & 158 & 1096699 & 39934091 & 153281281 & 732744698 & 24748048714 \\
13995 & 79 & 2000000 & 66758181 & 204382116 & 624332472 & 13204454560 \\
13996 & 79 & 3771500 & 38087590 & 181454545 & 796837380 & 15878919191 \\
13997 & 79 & 2637500 & 43983545 & 225374935 & 622490400 & $3.30946 \mathrm{E}+11$ \\
13999 & 234 & 2100000 & 67625250 & 190668207 & 700109420 & 23512729496 \\
\hline
\end{tabular}

Ringkasan data seperti di atas tidak dapat dianalisis menggunakan Benford's law karena Benford's law membutuhkan data sebelum diringkas. Oleh karena itu, paper ini menggunakan isi tabel di atas sebagai acuan untuk membangkitkan simulasi data Faktur Pajak secara acak. Proses pembangkitan data ini dilakukan dengan basis distribusi triangular. Distribusi ini dipilih karena pada data ringkasan di atas terdapat tiga variabel yang diperlukan untuk menghasilkan angka acak, yaitu minimum, maksimum, dan Q2. Selain menggunakan triangular, proses pembangkitan data dapat menggunakan distribusi uniform atau normal. Distribusi uniform tidak dipergunakan karena harus menghilangkan Q2. Kemudian, distribusi normal juga tidak dipilih karena dalam tabel ringkasan di atas tidak terdapat mean dan standar deviasi. 
Proses pembuatan angka acak dilakukan menggunakan Minitab karena Excel tidak menyediakan fungsi yang siap pakai untuk distribusi triangular. Jumlah angka yang dibangkitkan disesuaikan dengan jumlah count data per KLU pada tabel di atas. Sebagai contoh, KLU 13999 memiliki 234 Faktur Pajak. Wajib Pajak pada KLU ini menyampaikan Faktur Pajak dengan DPP paling rendah sebesar Rp 2,1 juta dan paling tinggi sebesar $\mathrm{Rp}$ 23.512.729.496,00. Nilai tengahnya adalah sebesar Rp 190.668.207,00. Sesuai dengan kriteria tersebut, kotak dialog random data generator Minitab diberikan input sebagai berikut ini.

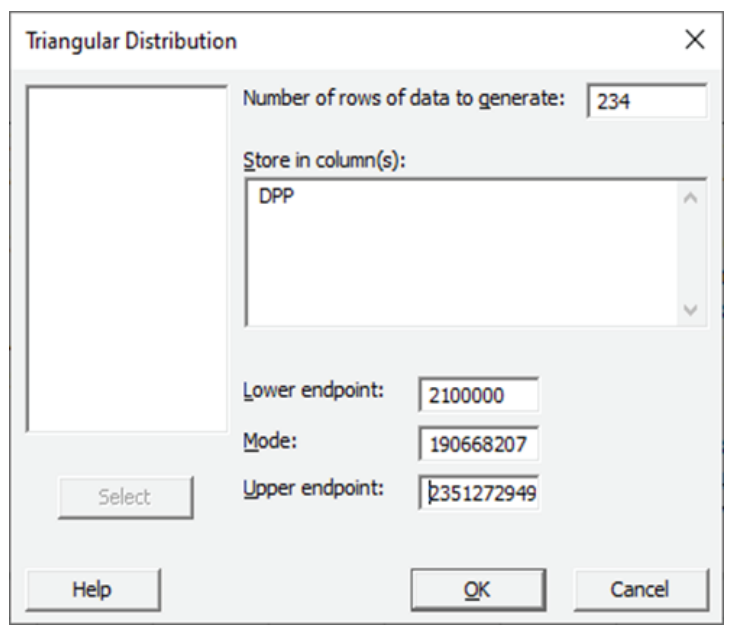

Proses ini menghasilkan 234 angka acak dengan nilai minimum, maksimum, dan median sesuai dengan input di atas. Hal tersebut terus diulang untuk setiap KLU menggunakan kriteria sesuai dengan data yang diperoleh pada tabel di atas. Pada akhirnya diperoleh data sejumlah 125.118 records yang dibangkitkan secara acak dengan random data generator.
Jumlah records ini sesuai dengan jumlah seluruh Faktur Pajak dalam ringkasan yang diperoleh peneliti. Dengan demikian, data hasil proses pembangkitan tersebut memiliki sebaran yang sama dengan sebaran data yang ringkasannya diperoleh oleh peneliti. Contoh sebagian data yang dibangkitkan menggunakan proses di atas untuk KLU 13999 adalah sebagai berikut ini

\begin{tabular}{cc}
\hline KLU & DPP \\
\hline 13999 & $9,965,213,004.00$ \\
13999 & $6,873,472,000.00$ \\
13999 & $6,680,726,242.00$ \\
13999 & $5,883,222,574.00$ \\
13999 & $5,215,204,397.00$ \\
13999 & $5,117,358,304.00$ \\
13999 & $4,046,246,258.00$ \\
13999 & $3,515,561,761.00$ \\
13999 & $3,227,440,991.00$ \\
13999 & $3,140,733,716.00$ \\
13999 & $2,562,364,521.00$ \\
13999 & $2,523,337,671.00$ \\
13999 & $2,394,865,904.00$ \\
13999 & $2,372,274,823.00$ \\
13999 & $2,266,875,289.00$ \\
\hline
\end{tabular}

Data-data ini selanjutnya dianalisis menggunakan Benford's law. 